\title{
Impact of 16S rRNA gene redundancy and primer pair selection on the quantification and classification of oral microbiota in next-generation sequencing
}

\author{
Alba Regueira-Iglesias \\ Universidade de Santiago de Compostela - Campus de Santiago: Universidade de Santiago de \\ Compostela

\section{Lara Vázquez-González} \\ Universidade de Santiago de Compostela - Campus de Santiago: Universidade de Santiago de \\ Compostela
}

\section{Carlos Balsa-Castro}

Universidade de Santiago de Compostela - Campus de Santiago: Universidade de Santiago de Compostela

\section{Triana Blanco-Pintos}

Universidade de Santiago de Compostela - Campus de Santiago: Universidade de Santiago de Compostela

\section{Nicolás Vila-Blanco}

Universidade de Santiago de Compostela - Campus de Santiago: Universidade de Santiago de Compostela

\section{María José Carreira}

Universidade de Santiago de Compostela - Campus de Santiago: Universidade de Santiago de Compostela

Inmaculada Tomás ( $\square$ inmaculada.tomas@usc.es )

Universidade de Santiago de Compostela - Campus de Santiago: Universidade de Santiago de Compostela https://orcid.org/0000-0002-3317-0853

\section{Research}

Keywords: $16 \mathrm{~S}$ rRNA gene, gene variant, matching amplicon, oral microbiota, overestimation factor, primer, redundancy, sequence analysis

Posted Date: July 1st, 2021

DOI: https://doi.org/10.21203/rs.3.rs-662236/v1 
License: (c) (i) This work is licensed under a Creative Commons Attribution 4.0 International License. Read Full License 


\section{Abstract}

Background: The identification, at least at the species level, is highly desirable in 16S rRNA sequencingbased studies of the oral microbiota. However, no study in the oral microbiology field has examined the impact of which primer pair is selected to detect redundant and matching amplicons. Consequently, our aims were to: 1) evaluate the number of 16S rRNA genes in the complete genomes of all the bacterial and archaeal species ever detected in the human oral cavity; and 2) assess how the use of different primer pairs would affect the detection and classification of redundant amplicons and matching amplicons (MA) from different taxa.

Results: A total of 709 complete genomes (518 bacteria, 191 archaea) were downloaded from the NCBI database, and their complete 16S rRNA genes were extracted. $94.1 \%$ of oral bacteria and $52.59 \%$ of oral archaea had more than one 16S rRNA gene in their respective genomes. Next, 33 primer pairs identified in previous research and 6 commonly used in the literature were used against all the genomes to obtain amplicons. Between $46.67 \%-1.29 \%$ of the bacterial species and between $38.89 \%-4.65 \%$ of the archaeal species had MA, affecting relevant genera present in the oral environment such as Actinomyces, Fusobacterium, Lactobacillus, Methanosarcina, Staphylococcus, and Streptococcus. The best primer pairs were (the species coverage with no MA values, SC-NMA; region; primer pair position for Escherichia coli J01859.1): KP_F048-OP_R030 for bacteria (93.55\%; 3-7; 342-1079), KP_F018-KP_R063 for archaea (89.63\%; 3-9; undefined-1506), and OP_F114_OP_R121 for both bacteria and archaea $(92.52 \%$; 3-9; 3401405).

Conclusions: In addition to the 16S rRNA gene redundancy, the considerable presence of matching amplicons must be controlled to ensure the accurate interpretation of microbial diversity data. The SCNMA is a more useful parameter than the conventional coverage percentage for selecting the best primer pairs. The performance of the primer pairs to detect no MA species increases as the average length of the amplicons increases; none of these being the most widely used primer pairs in the oral literature. The choice of primer pair affects significantly diversity estimates and taxonomic classification, conditioning the comparability of oral microbiome studies using different primer pairs.

\section{Full Text}

This preprint is available for download as a PDF.

\section{Supplementary Files}

This is a list of supplementary files associated with this preprint. Click to download.

- Additionalfile1.xlsx

- Additionalfile10.xIsx

- Additionalfile11.xlsx 
- Additionalfile12.xlsx

- Additionalfile13.xlsx

- Additionalfile14.xIsx

- Additionalfile15.xIsx

- Additionalfile16.xlsx

- Additionalfile2.xIsx

- Additionalfile3.xIsx

- Additionalfile4.xlsx

- Additionalfile5.xIsx

- Additionalfile6.xIsx

- Additionalfile7.xlsx

- Additionalfile8.xIsx

- Additionalfile9.xlsx 